\title{
Sistem Informasi Penjualan Online Hasil Tani Desa Blukbuk Berbasis Aplikasi Website.
}

\author{
Irfan Ricky Afandi' ${ }^{1)}$, Yusuf Handika ${ }^{2)}$, Isa Faqihuddin Hanif ${ }^{3)}$, Dede Ismail ${ }^{4}$ \\ 1,2,3,4)Teknik Informatika Universitas Muhammadiyah Prof. Dr. Hamka \\ Jl. Tanah Merdeka No.6, Pasar Rebo, Jakarta Timur Telp: 021-8778-2739 Fax - Mobile 0858-1300-1800 \\ Website: www.ft.uhamka.ac.id, E-mail: info@uhamka.ac.id
}

\begin{abstract}
Abstrak
Desa Blukbuk adalah sebuah desa yang sebagian besar mata pencaharian masyarakatnya berada pada sektor pertanian. Selama ini proses penjualan hasil pertanian di Desa Blukbuk masih dilakukan secara konvesional. Namun demikian, petani di Desa Blukbuk sering mengalami kesulitan dalam menjual hasil pertanian kepada konsumen. Tujuan dari penelitian ini adalah untuk membantu petani di Desa Blukbuk dalam menjual hasil pertanian kepada konsumen melalui sistem informasi penjualan online berbasis aplikasi website yaitu dengan menggunakan bahasa pemrograman PHP dan database MySQL. Dengan adanya perancangan sistem informasi penjualan online berbasis aplikasi website diharapkan dapat memperkenalkan produk-produk pertanian di Desa Blukbuk ke masyarakat luas dan dapat meningkatkan perekonomian di Desa Blukbuk.
\end{abstract}

Kata kunci: sistem informasi penjualan online, website, $P H P, M y S Q L$

\begin{abstract}
Blukbuk Village is a village where most of the people's livelihoods are in the agricultural sector. So far, the process of selling agricultural products in Blukbuk Village is still carried out conventionally. However, farmers in Blukbuk Village often experience difficulties in selling agricultural products to consumers. The purpose of this research is to assist farmers in Blukbuk Village in selling agricultural products to consumers through an online sales information system based on a website application using the PHP programming language and MySQL database. With the design of an online sales information system based on a website application, it is hoped that it can introduce agricultural products in Blukbuk Village to the wider community and can improve the economy in Blukbuk Village.
\end{abstract}

Keyword: online sales information system, website, PHP, MySQL.

\section{PENDAHULUAN}

Seiring berjalannya waktu kemajuan teknologi informasi berkembang cukup pesat dan membuat manusia memasuki zaman baru yaitu di era teknologi. Dengan adanya teknologi memberi dampak positif kepada manusia yaitu dapat membantu meringankan beban aktivitas dalam kehidupan sehari-hari dan memudahkan manusia untuk memperoleh informasi yang cepat, tepat dan akurat. Teknologi internet merupakan salah satu perkembangan teknologi yang sering digunakan oleh manusia saat ini. Penggunaan teknologi internet tidak hanya dapat membantu manusia dalam mencari informasi, namun dapat dimanfaatkan untuk melakukan kegiatan proses jual beli secara online dengan menggunakan media website. Proses digitalisasi jual beli melalui media website dikenal dengan istilah sistem informasi penjualan online berbasis aplikasi website [1]. Dengan adanya sistem tersebut manusia dapat mempromosikan dan menjual produknya ke pasar global dan dapat membangun hubungan yang baik dengan konsumen. Kini dengan adanya teknologi internet dapat memudahkan manusia dalam melakukan proses transaksi jual beli.

Desa Blukbuk adalah desa yang berlokasi di Kecamatan Kronjo, Kabupaten Tangerang, Provinsi Banten. Sebagian besar mata pencaharian warga Desa Blukbuk yaitu berada pada sektor pertanian. Biasanya petani di Desa Blukbuk memanfaatkan lahan kosong di pekarangan rumahnya untuk dijadikan sebagai lahan menanam sayur dan buah. Proses penjualan hasil pertanian di Desa Blukbuk masih dilakukan secara konvensional, dimana petani menjual hasil pertanian kepada tengkulak untuk kemudian dibawa ke pasar dan dijual kembali kepada konsumen. Hal ini membuat petani di Desa Blukbuk mendapatkan keuntungan yang tidak banyak karena hanya mengambil selisih sedikit dari harga beli dari tengkulak. Selain itu masalah yang dihadapi oleh petani di Desa Blukbuk yaitu pemasaran produk hanya dapat menjual produk dengan jangkauan pasar yang terbatas. Dimana konsep penjualan seperti ini harus mengalami perubahan jika petani di Desa Blukbuk ingin mendapatkan keuntungan yang lebih besar, yaitu dengan cara melakukan pemasaran produk secara langsung kepada konsumen [2].

DOI: 10.22236/teknoka.v5i.334 
Saat ini di Desa Blukbuk masih belum memiliki sarana publikasi maupun promosi untuk menjual hasil pertanian, sehingga konsumen tidak mengetahui produk apa saja yang di jual di Desa Blukbuk. Kegiatan promosi adalah suatu hal yang terpenting untuk memasarkan sebuah produk serta meningkatkan kualitas penjualan [3]. Sedangkan dalam kegiatan promosi membutuhkan sebuah media yang dapat membantu penjual untuk memperkenalkan semua produk kepada konsumen. Oleh karena itu sangat penting bagi petani di Desa Blukbuk untuk memahami konsep sistem informasi penjualan online berbasis aplikasi website sehingga dapat memutus mata rantai penjualan yang panjang menjadi sistem yang lebih ringkas. Tujuan penelitian ini yaitu untuk membantu petani di Desa Blukbuk dalam mempromosikan dan menjual hasil pertanian dengan jangkauan pasar yang lebih luas serta memberikan pelayanan yang baik kepada konsumen dengan merancang sebuah sistem informasi penjualan online berbasis aplikasi website di Desa Blukbuk.

\section{LANDASAN TEORI}

\subsection{Promosi}

Promosi adalah semua aktivitas yang berkaitan dengan penyampaian informasi mengenai sebuah produk [4]. Tujuan dari kegiatan promosi yaitu untuk memperkenalkan sebuah produk dan mempengaruhi konsumen untuk membeli produk yang ditawarkan sehingga dapat meningkatkan penjualan.

\subsection{Sistem Informasi}

Sistem informasi adalah sekumpulan komponen (brainware, hardware, software, jaringan komunikasi dan sumber daya data) yang dimana komponen-komponen tersebut saling terintegrasi antara satu dengan yang lain untuk mengumpulkan, memproses, mengubah dan menyebarkan informasi dalam sebuah organisasi atau perusahaan [5].

\subsection{Penjualan Online}

Penjualan online adalah aktivitas menjual produk atau jasa dengan menggunakan media elektronik seperti internet [6]. Salah satu kelebihan dari penjualan online yaitu dapat melakukan kegiatan promosi dengan cepat dan relevan sesuai dengan kebutuhan dari konsumen.

\subsection{Website}

Website adalah sekumpulan halaman pada sebuah domain di internet yang dibuat dengan tujuan tertentu serta dapat diakses secara luas dengan menggunakan browser [7]. Dalam sebuah website terdapat tiga unsur penting agar sebuah website dapat diakses oleh user di internet yaitu domain, hosting, dan

Copyright (C) 2020 FT-UHAMKA. - All rights reserved DOI: 10.22236/teknoka.v5i.334 konten.

2.5. HTML (Hypertext Markup Language)

HTML (Hypertext Markup Language) adalah sebuah bahasa pemrograman yang digunakan untuk membuat struktur dari sebuah halaman website [8]. HTML dapat digunakan untuk menulis teks atau paragraf, memasukkan gambar, membuat form dan lain sebagainya.

2.6. PHP (Hypertext Preprocessor)

PHP (Hypertext Preprocessor) adalah sebuah bahasa pemrograman multiplatform atau dapat berjalan di berbagai sistem operasi (Linux, Unix, Macintosh, Windows) dan dapat dijalankan secara runtime melalui console [9]. PHP dapat digunakan untuk membuat sebuah tampilan website yang dinamis dan interaktif. Dinamis yang berarti tampilan website tersebut dapat disesuaikan dengan keinginan. Interaktif yang berarti website terebut dapat memberikan feedback bagi para pengguna (User).

\subsection{Database MySQL}

Database MySQL adalah sebuah software yang digunakan untuk melakukan sistem manajemen basis data SQL atau DBMS yang multithread dan multi-user [10]. MySQL dapat digunakan untuk membuat sebuah database atau tabel serta menambah, mengubah, menghapus dan mengambil data pada database tersebut.

\subsection{XAMPP}

XAMPP adalah sebuah software opensource yang dapat berfungsi sebagai server lokal (localhost) [11]. Dengan menggunakan XAMPP user dapat modifikasi sebuah website tanpa harus terhubung dengan internet.

\subsection{Black Box Testing}

Black box testing adalah suatu pengujian yang dilakukan dengan cara menjalankan atau mengeksekusi sebuah sistem dengan memberikan suatu masukan yang kemudian akan diamati hasil akhirnya. [12].

\section{PERANCANGAN SISTEM}

Pada gambar 1 menunjukkan bagaimana diagram alir dari perancangan sistem informasi penjualan online hasil tani Desa Blukbuk berbasis aplikasi website yang akan dilakukan.

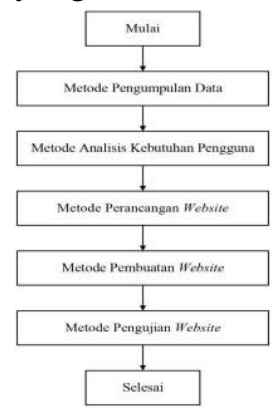

Gambar 1. Diagram Alir Perancangan Sistem.

Seminar Nasional TEKNOKA ke - 5, Vol. 5, 2020 ISSN No. 2502-8782 
Dengan adanya perancangan sistem tersebut diharapkan dapat menjadi salah satu solusi untuk membantu petani di Desa Blukbuk dalam menjual dan memperkenalkan produk hasil pertanian ke masyarakat luas, sehingga dapat meningkatkan perekonomian di Desa Blukbuk.

\subsection{Pengumpulan Data}

Tahap pertama dalam penelitian ini adalah pengumpulan data yang dilakukan melalui observasi, wawancara dan studi literatur. Observasi lapangan bertujuan untuk mengetahui proses kegiatan jual beli secara langsung di Desa Blukbuk. Kegiatan wawancara dilakukan untuk mencari informasi tentang permasalahan yang dialami oleh petani di Desa Blukbuk. Narasumber dalam kegiatan penelitian ini adalah kepala desa dan beberapa petani di Desa Blukbuk. Adapun permasalahan utama yang dialami oleh petani di Desa Blukbuk yaitu petani masih mengalami kesulitan dalam menjuah hasil pertanian kepada konsumen. Studi literatur bertujuan untuk memperkuat ide dalam mencari solusi yang berhubungan dengan penelitian sehingga tujuan perancangan sistem informasi penjualan online hasil tani di Desa Blukbuk dapat terealisasikan dengan baik. Adapun literatur yang digunakan dalam penelitian ini yaitu buku-buku, jurnal ilmiah, artikel ilmiah, maupun dari penelitian yang sudah dilakukan sebelumnya oleh orang lain.

\subsection{Analisis Kebutuhan Pengguna}

Tahap kedua dalam penelitian ini adalah melakukan analisis kebutuhan dari sisi pengguna. Adapun tingkatan pengguna dalam sistem informasi website ini yaitu user dan admin. User adalah seseorang yang dapat melihat informasi mengenai produk dan dapat melakukan pemesanan produk. Admin adalah seseorang yang mengatur website seperti meng-update informasi terbaru, mengelola data pemesanan, mengontrol kesalahan dan keamanan pada sistem.

\subsection{Perancangan Website}

Tahap ketiga dalam penelitian ini adalah perancangan website, yaitu membuat tampilan mockup halaman website dan relasi dari setiap halaman tersebut. Terdapat lima halaman utama yang akan dibuat yaitu halaman masuk, beranda, toko, keranjang dan pemesanan produk.

\subsection{Pembuatan Website}

Tahap keempat dalam penelitian ini adalah pembuatan website berdasarkan tampilan mockup yang sudah dibuat dengan menggunakan bahasa pemrograman PHP dan diintegrasikan dengan database MySQL.

\subsection{Pengujian Website}

Tahap kelima dalam penelitian ini adalah pengujian website, yaitu memastikan setiap komponen website dapat bekerja dengan baik dengan menggunakan metode black box testing. Proses pengujian website meliputi proses pembuatan akun, menambahkan produk ke dalam keranjang dan pemesanan produk. Selanjutnya yaitu membuat kesimpulan dari hasil pengujian yang sudah dilakukan.

\section{IMPLEMENTASI DAN PENGUJIAN}

Implementasi adalah penerapan suatu aktivitas untuk mencapai tujuan tertentu atau sasaran [13]. Pada tahap ini akan membahas tentang sistem informasi penjualan online hasil tani Desa Blukbuk berbasis aplikasi website yang sudah dibangun.

\subsection{Implementasi Halaman Website \\ 4.1.1. Tampilan Halaman Masuk}

Pada gambar 2 menampilkan halaman masuk dari sistem informasi penjualan online hasil tani Desa Blukbuk berbasis aplikasi website. Dimana terdapat dua pilihan kolom yaitu kolom untuk masuk (login) dan kolom pendaftaran (register). User baru yang belum memiliki akun harus melakukan pendaftaran terlebih dahulu yaitu dengan memasukkan beberapa informasi seperti nama lengkap, alamat email dan kata sandi. Bagi user yang sudah memiliki akun bisa memasukkan alamat email dan kata sandi pada kolom masuk.

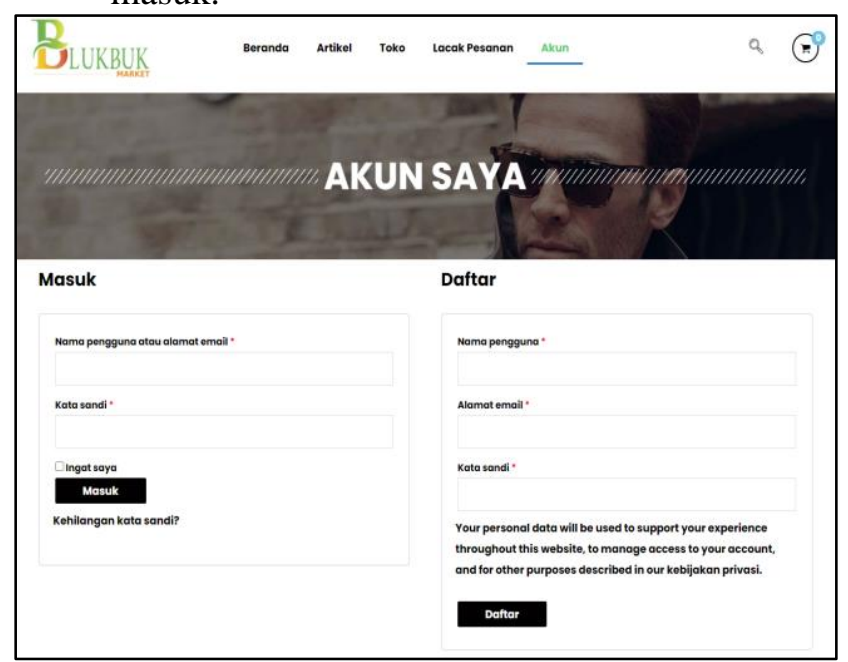

Gambar 2. Tampilan Halaman Masuk.

\subsubsection{Tampilan Halaman Beranda}

Pada gambar 3 menampilkan halaman beranda dari sistem informasi penjualan online hasil tani Desa Blukbuk berbasis aplikasi website. Dimana terdapat logo dan informasi tentang aplikasi Blukbuk Market, serta cara melakukan proses pemesanan, menampilkan produk terbaru dan artikel 
tentang Desa Blukbuk.

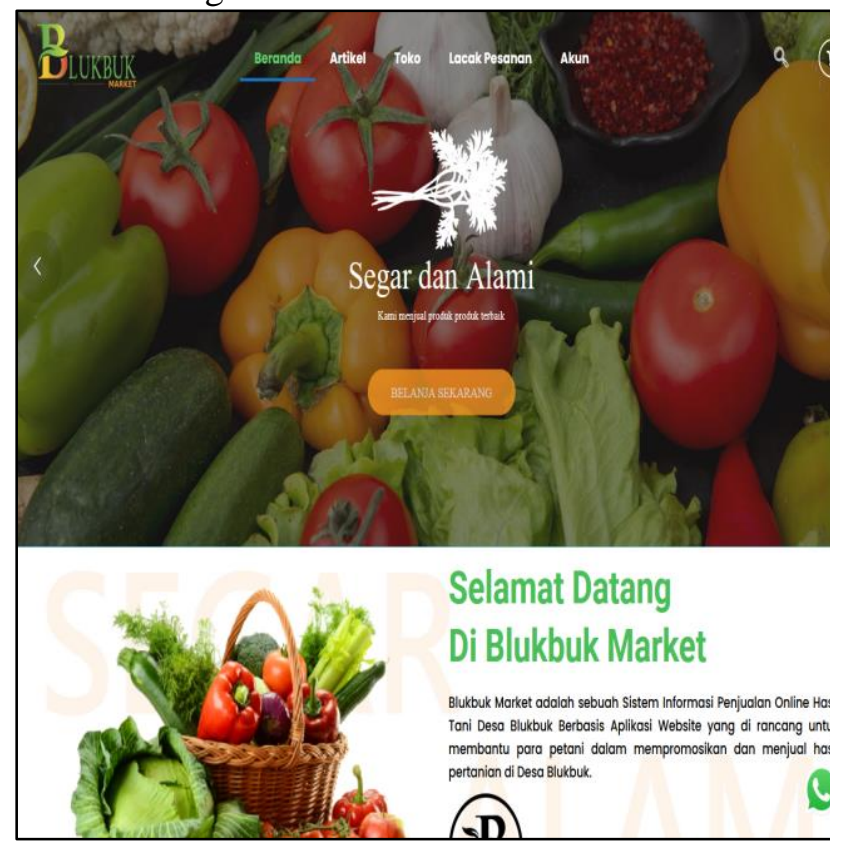

Gambar 3. Tampilan Halaman Beranda.

\subsubsection{Tampilan Halaman Toko}

Pada gambar 4 menampilkan tampilan halaman toko dari sistem informasi penjualan online hasil tani Desa Blukbuk berbasis aplikasi website. Dimana terdapat informasi produk hasil pertanian yang di jual di Desa Blukbuk dan fitur saring produk berdasarkan harga atau kategori produk.

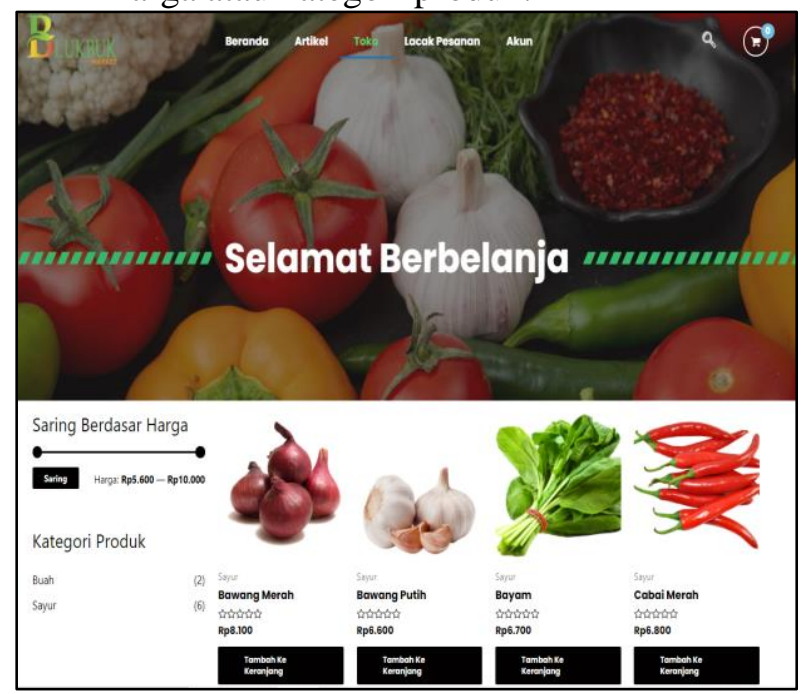

Gambar 4. Tampilan Halaman Toko

\subsubsection{Tampilan Halaman Keranjang}

Pada gambar 5 menampilkan tampilan halaman keranjang dari sistem informasi penjualan online hasil tani Desa Blukbuk berbasis aplikasi website. Dimana halaman tersebut menampilkan semua produk yang sudah dipilih oleh user dan nantinya akan dilakukan proses pemesanan.

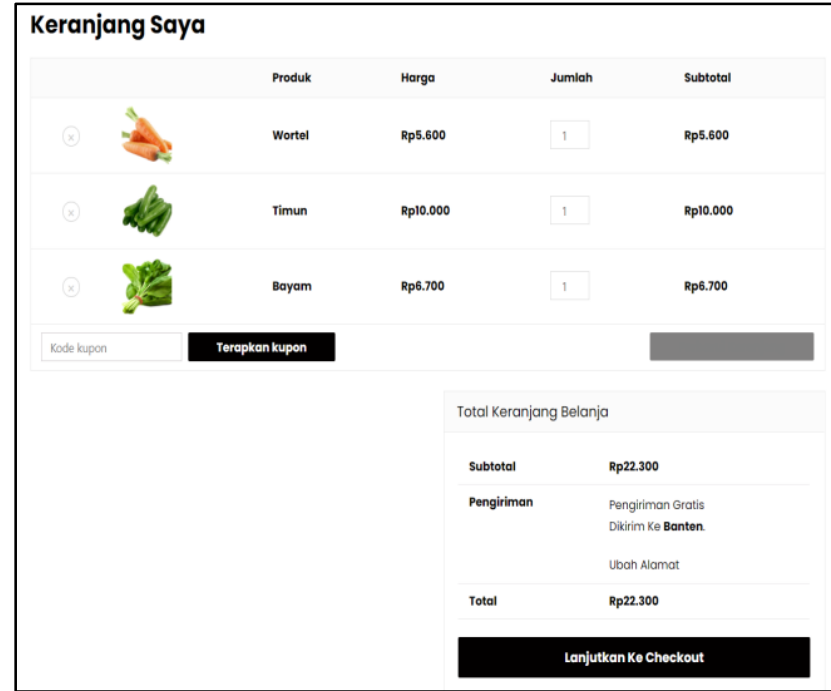

Gambar 5. Tampilan Halaman Keranjang.

4.1.5. Tampilan Halaman Pemesanan Produk

Pada gambar 6 menampilkan halaman pemesanan produk dari sistem informasi penjualan online hasil tani Desa Blukbuk berbasis aplikasi website. Dimana halaman tersebut menampilkan detail dan harga produk yang akan di beli oleh user serta form alamat dan metode pembayaran.

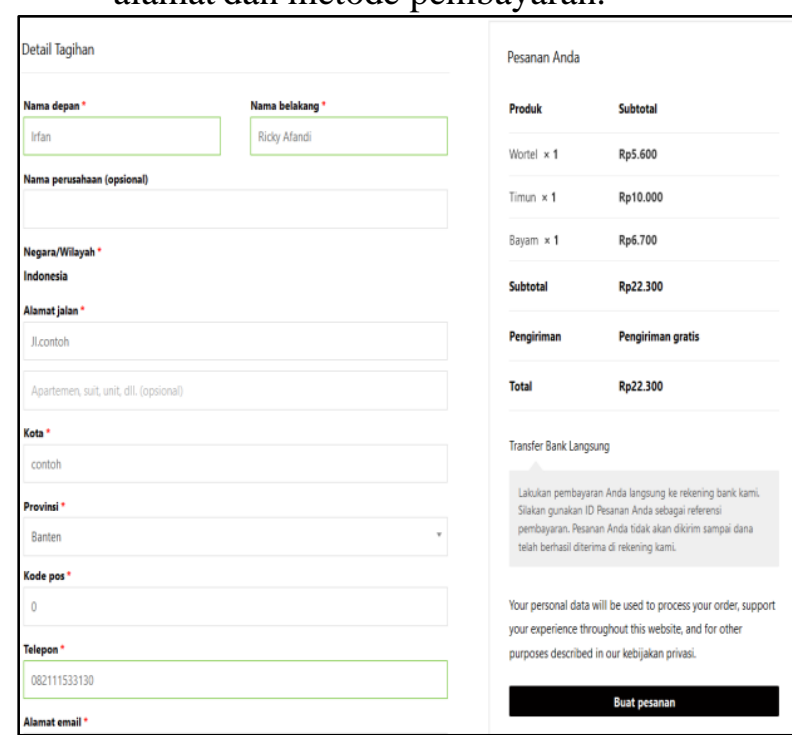

Gambar 6. Tampilan Halaman Pemesanan Produk.

4.2. Implementasi Database

\subsubsection{Tampilan Database Pengguna}

Pada gambar 7 menampilkan database pengguna dari sistem informasi penjualan online hasil tani Desa Blukbuk berbasis aplikasi website. Dimana terdapat beberapa field yaitu user_login, user_pass, user_nickname, user_email, user_url dan user_registered. 


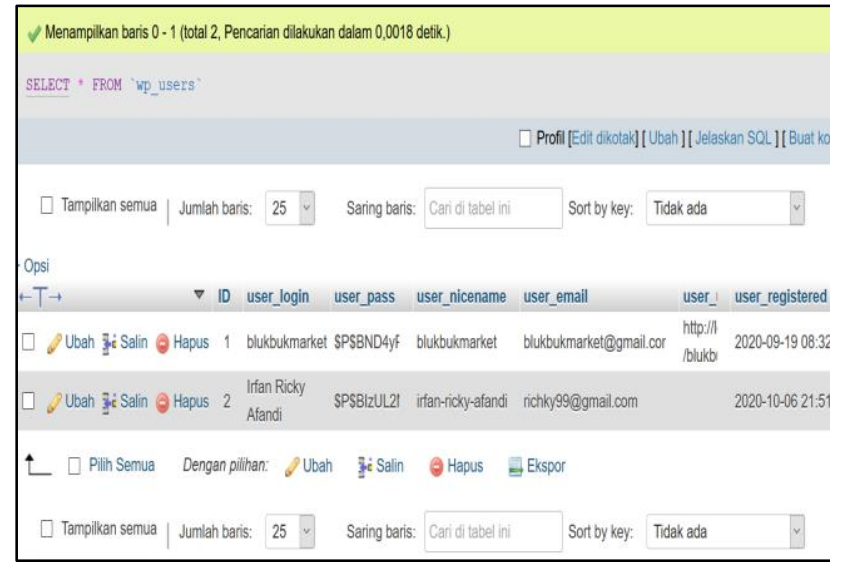

Gambar 7. Tampilan Database Pengguna.

\subsubsection{Tampilan Database Produk}

Pada gambar 8 menampilkan database produk. Dimana terdapat beberapa field yaitu product_id, min, max, stock_quality dan stock_status.

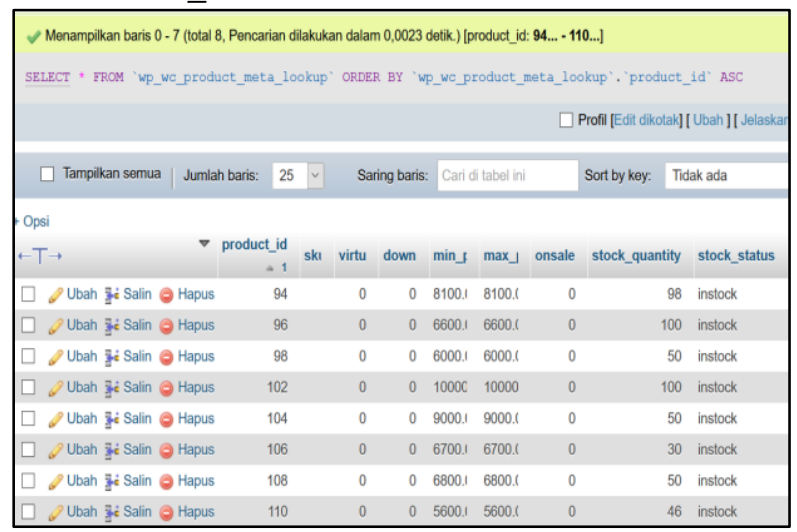

Gambar 8. Tampilan Database Produk.

\subsubsection{Tampilan Database Pemesanan}

Pada gambar 9 menampilkan tampilan database pemesanan. Dimana terdapat beberapa field yaitu order_id, date_created, num_item_sold dan total_sales.

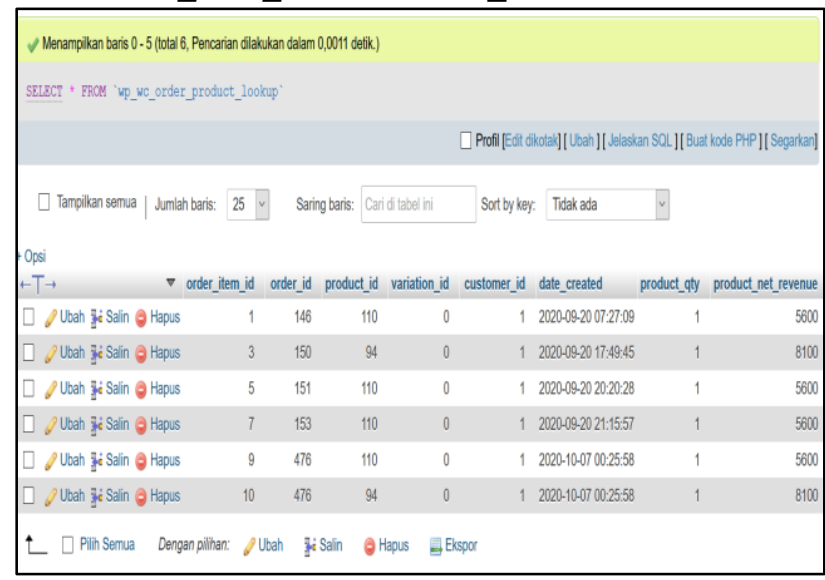

Gambar 9. Tampilan Database Pemesanan.

\subsection{Hasil Pengujian Website}

\subsubsection{Pengujian Proses Pembuatan Akun}

Pada gambar 10 menampilkan data seorang user baru yang akan melakukan pendaftaran. Proses pembuatan akun dilakukan dengan skenario yaitu seorang user yang belum mempunyai akun dan akan melakukan pendaftaran pada halaman masuk dengan mengisi data pada kolom pendaftaran.

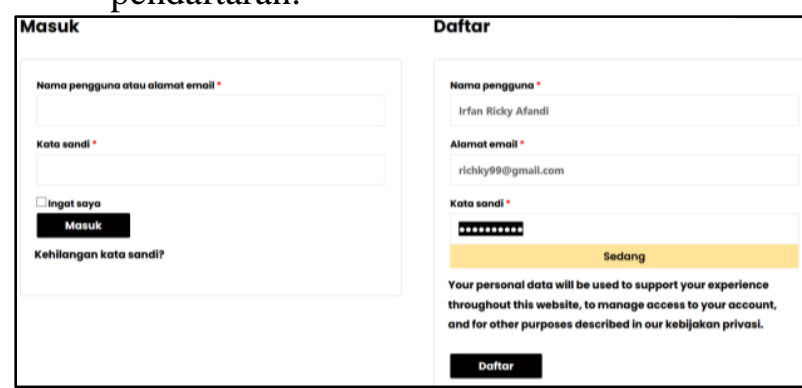

Gambar 10. Proses Pembuatan Akun.

Pada gambar 11 menampilkan proses pembuatan akun user baru yang berhasil. Apabila proses pendaftaran berhasil maka sistem akan menampilkan halaman akun pengguna.

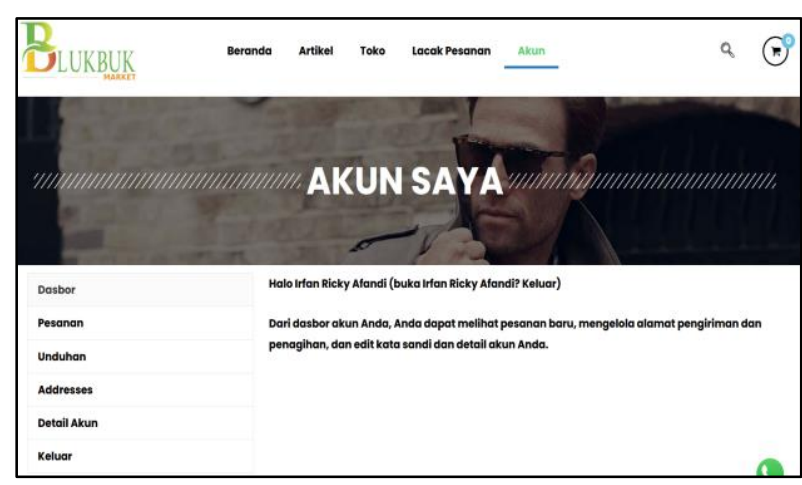

Gambar 11. Proses Pembuatan Akun Berhasil.

Pada tabel 1 menampilkan hasil pengujian proses pembuatan akun dengan menggukan metode black box testing. Dimana proses pengujian dilakukan dengan skenario seorang user yang menginputkan semua data pada form pendaftaran dan ketika seorang user yang hanya menginputkan sebagian data.

Tabel 1. Pegujian Pembuatan Akun Dengan Black Box Testing.

\begin{tabular}{|c|c|c|c|c|}
\hline Id & $\begin{array}{l}\text { Deskripsi } \\
\text { Pengujian }\end{array}$ & $\begin{array}{l}\text { Hasil Yang } \\
\text { Diharapkan }\end{array}$ & $\begin{array}{c}\text { Hasil } \\
\text { Pengujian }\end{array}$ & Ket \\
\hline A01 & $\begin{array}{l}\text { User ingin } \\
\text { melakukan } \\
\text { pendaftaran } \\
\text { dengan } \\
\text { mengisi form } \\
\text { di kolom } \\
\text { "Daftar" } \\
\text { dengan } \\
\text { mengisikan } \\
\text { Nama } \\
\text { pengguna, } \\
\text { Alamat } \\
\text { Email, dan } \\
\text { Kata Sandi } \\
\text { lalu } \\
\text { kemudian } \\
\text { menekan } \\
\text { tombol } \\
\text { "Daftar". }\end{array}$ & $\begin{array}{l}\text { Sistem } \\
\text { menerima dan } \\
\text { menampilkan } \\
\text { halaman akun } \\
\text { user. }\end{array}$ & $\begin{array}{l}\text { Sistem } \\
\text { menampilkan } \\
\text { halaman akun } \\
\text { user. }\end{array}$ & Berhasil \\
\hline
\end{tabular}
ISSN No. 2502-8782 


\begin{tabular}{|l|l|l|l|l|}
\hline & User ingin & Sistem akan & Sistem & Berhasil \\
melakukan & menolak dan & menampilkan & \\
pendaftaran & menampilkan & pemberitahuan & \\
dengan & pemberitahuan & "Tolong & \\
mengisi form & "Tolong & Lengkapi & \\
di kolom & Lengkapi & Semua Data & \\
"Daftar" & Semua Data & Diri Anda" & \\
dengan tidak & Diri Anda" & & \\
mengisikan & & & \\
data pada & & & \\
form dan & & & \\
kemudian & & & \\
menekan & & & \\
tombol & & & \\
"Daftar" & & & \\
\hline
\end{tabular}

\subsubsection{Pengujian Proses Menambahkan Produk Ke Dalam Keranjang}

Pada gambar 12 menampilkan contoh sebuah produk yang akan dimasukkan ke dalam keranjang. Proses menambahkan produk ke dalam keranjang dilakukan dengan skenario dimana user sudah memilih sebuah produk kemudian menekan tombol "tambahkan ke keranjang".

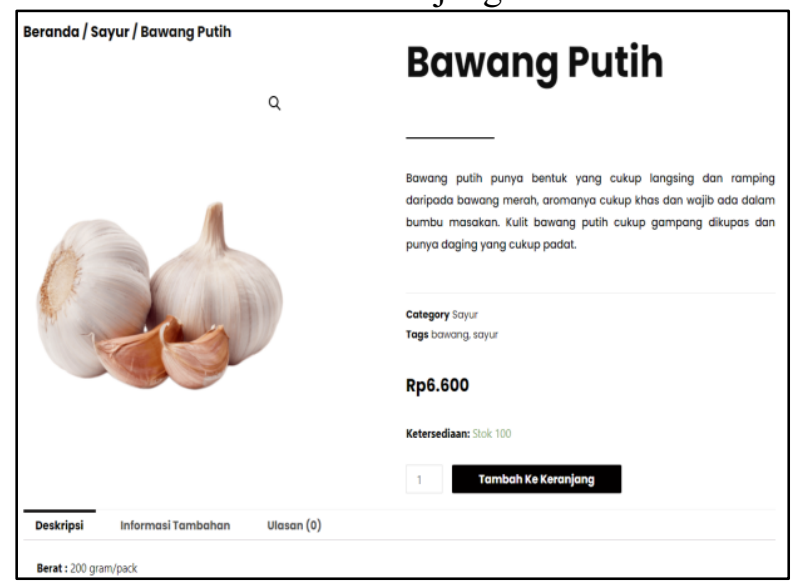

Gambar 12. Proses Menambahkan Produk Ke Dalam Keranjang.

Pada gambar 13 menampilkan proses menambahkan produk ke dalam keranjang yang berhasil. Apabila proses menambahkan produk ke dalam keranjang berhasil maka pada halaman keranjang akan menampilkan produk yang sudah dipilih oleh $u$ ser.

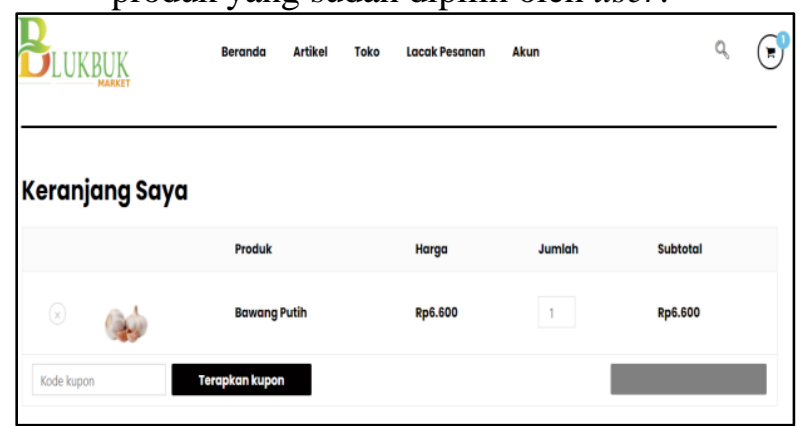

Gambar 13. Proses Menambahkan Produk Ke Dalam Keranjang Berhasil.

Pada tabel 2 menampilkan hasil pengujian proses menambahkan produk ke dalam keranjang dengan metode black box testing. Dimana proses pengujian dilakukan dengan skenario seorang user yang memilih produk dengan menekan gambar produk dan menekan tombol tambahkan produk ke dalam keranjang.

Tabel 2. Pengujian Menambahkan Produk Ke Keranjang Dengan Black Box Testing.

\begin{tabular}{|c|l|l|l|l|}
\hline Id & \multicolumn{1}{|c|}{$\begin{array}{c}\text { Deskripsi } \\
\text { Pengujian }\end{array}$} & \multicolumn{1}{|c|}{$\begin{array}{c}\text { Hasil Yang } \\
\text { Diharapkan }\end{array}$} & \multicolumn{1}{c|}{$\begin{array}{c}\text { Hasil } \\
\text { Pengujian }\end{array}$} & Ket \\
\hline B01 & $\begin{array}{l}\text { User memilih } \\
\text { produk yang } \\
\text { akan di beli } \\
\text { dengan } \\
\text { melihatnya di } \\
\text { halaman toko } \\
\text { dan selanjutnya } \\
\text { menekan } \\
\text { gambar produk. }\end{array}$ & $\begin{array}{l}\text { Sistem } \\
\text { menerima dan } \\
\text { menampilkan } \\
\text { halaman detail } \\
\text { produk. }\end{array}$ & $\begin{array}{l}\text { Sistem } \\
\text { menampilkan } \\
\text { halaman } \\
\text { detail produk. }\end{array}$ & Berhasil \\
\hline B02 & $\begin{array}{l}\text { User } \\
\text { menambahkan } \\
\text { produk ke } \\
\text { dalam } \\
\text { keranjang } \\
\text { dengan } \\
\text { mengklik } \\
\text { tombol } \\
\text { tambahkan } \\
\text { produk. }\end{array}$ & $\begin{array}{l}\text { Sistem } \\
\text { menerima dan } \\
\text { menyimpan } \\
\text { data pada } \\
\text { database. }\end{array}$ & $\begin{array}{l}\text { Sistem } \\
\text { menyimpan } \\
\text { data pada } \\
\text { database. }\end{array}$ & Berhasil \\
& & & \\
& & & \\
\end{tabular}

\subsubsection{Pengujian Proses Pemesanan Produk}

Pada gambar 14 menampilkan proses pemesanan produk. Proses pemesanan produk dilakukan dengan skenario seorang user yang sudah menambahkan produk ke dalam keranjang kemudian menekan tombol "lanjut ke checkout".

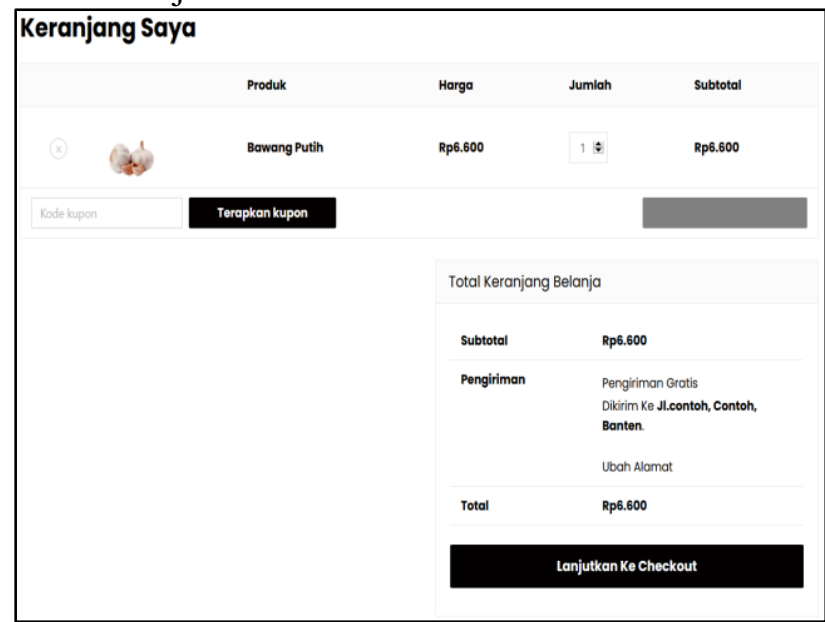

Gambar 14. Proses Pemesanan Produk.

Setelah menekan tombol "lanjut ke checkout" maka sistem akan menampilkan halaman halaman form seperti pada gambar 15. Pada halaman ini user harus mengisi alamat tujuan pengiriman dan memilih metode pembayaran. 


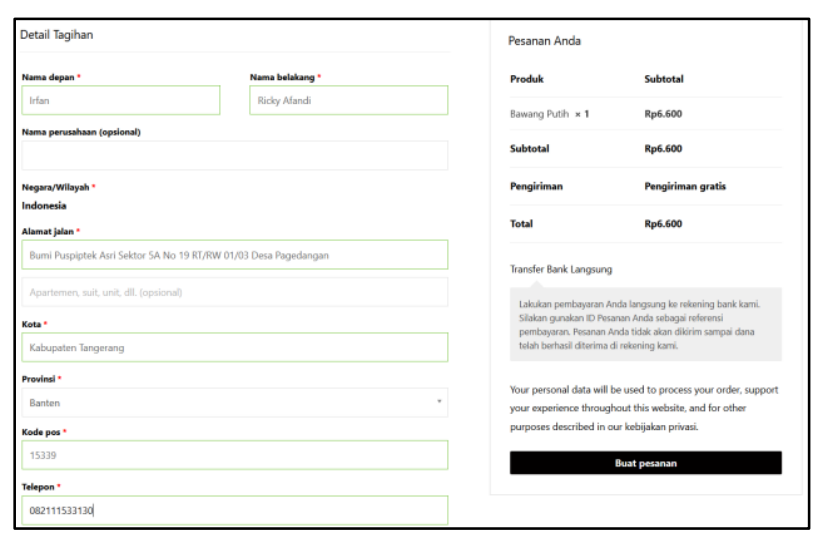

Gambar 15. Menampilkan Form Alamat Pengiriman.

Pada gambar 16 menampilkan proses pemesanan produk yang berhasil. Apabila proses pesanan berhasil dibuat maka user akan diarahkan ke halaman pesanan berhasil.

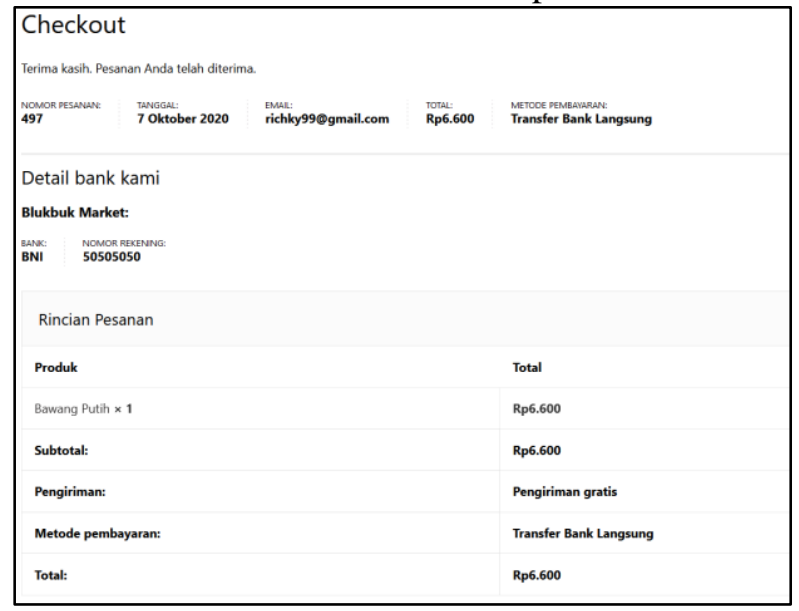

Gambar 16. Proses Pemesanan Berhasil.

Pada tabel 3 menampilkan hasil pengujian proses pemesanan produk dengan metode black box testing. Dimana proses pengujian dilakukan dengan skenario seorang user sudah menambahkan produk ke dalam keranjang kemudian menekan tombol checkout dan mengisi form pengiriman kemudian menekan tombol buat pesanan.

Tabel 3. Pengujian Pemesanan Produk Dengan Black Box

\begin{tabular}{|c|c|c|c|c|}
\hline \multicolumn{5}{|c|}{ Testing. } \\
\hline Id & $\begin{array}{l}\text { Deskripsi } \\
\text { Pengujian }\end{array}$ & $\begin{array}{l}\text { Hasil Yang } \\
\text { Diharapkan }\end{array}$ & $\begin{array}{l}\text { Hasil } \\
\text { Pengujian }\end{array}$ & Ket \\
\hline $\mathrm{C} 01$ & $\begin{array}{l}\text { User telah } \\
\text { menambahkan } \\
\text { produk ke } \\
\text { dalam } \\
\text { keranjang lalu } \\
\text { kemudian } \\
\text { menekan } \\
\text { tombol } \\
\text { checkout. }\end{array}$ & $\begin{array}{l}\text { Sistem } \\
\text { menerima dan } \\
\text { menampilkan } \\
\text { halaman } \\
\text { checkout. }\end{array}$ & $\begin{array}{l}\text { Sistem } \\
\text { menampilkan } \\
\text { halaman } \\
\text { checkout. }\end{array}$ & Berhasil \\
\hline $\mathrm{CO} 2$ & $\begin{array}{l}\text { User mengisi } \\
\text { data terkait } \\
\text { informasi } \\
\text { penerima } \\
\text { barang, alamat } \\
\text { pengiriman dan } \\
\text { metode } \\
\text { pembayaran. } \\
\text { Lalu menekan }\end{array}$ & $\begin{array}{l}\text { Sistem } \\
\text { menerima dan } \\
\text { menampilkan } \\
\text { halaman } \\
\text { pemesanan } \\
\text { berhasil. }\end{array}$ & $\begin{array}{l}\text { Sistem } \\
\text { menampilkan } \\
\text { halaman } \\
\text { pemesanan } \\
\text { berhasil. }\end{array}$ & Berhasil \\
\hline
\end{tabular}

\begin{tabular}{|l|l|l|l|l|}
\hline & $\begin{array}{l}\text { tombol buat } \\
\text { pesanan }\end{array}$ & & & \\
\hline
\end{tabular}

\section{KESIMPULAN}

Adapun kesimpulan yang dapat diambil berdasarkan hasil penelitian yang telah dilakukan yaitu :

1. Penggunaan sistem informasi penjualan online berbasis website dapat membantu petani dalam mengelola hasil penjualannya secara mandiri dan dapat memutus rantai penjualan yang panjang sehingga kinerja dan penghasilan yang di dapat oleh petani di Desa Blukbuk dapat meningkat.

2. Dengan menerapkan sistem informasi penjualan online berbasis website dapat memberikan kemudahan kepada petani dalam memperkenalkan produk hasil pertanian ke masyarakat luas dan dapat meningkatkan perekonomian di Desa Blukbuk.

3. Dapat memberikan kemudahan kepada konsumen yang ingin membeli produk hasil pertanian di Desa Blukbuk secara online yang dapat diakses melalui media website tanpa harus keluar rumah.

\section{DAFTAR PUSTAKA}

[1] A. Ishaq, I. Maryani dan Anuri, "Sistem Informasi Penjualan Parfume Berbasis Web Pada Toko La Coga Parfume," Simposium Nasional Ilmu Pengetahuan dan Teknologi (SIMNASIPTEK), p. 240, 2017.

[2] H. Apriyani, Sismadi dan Sefrika, "Penggunaan Internet Of Things Dalam Pemasaran Produk Pertanian," Jusikom : Jurnal Sistem Komputer Musirawas Vol 3 , No. 2, Desember, p. 83, 2018.

[3] M. F. R. NST dan H. Yasin, "Pengaruh Promosi Dan Harga Terhadap Minat Beli Perumahan Obama Pt. Nailah Adi Kurnia Sei Mencirim Medan," Jurnal Manajemen \& Bisnis Vol. 14 No. O2 Oktober, p. 139, 2014.

[4] V. Marudut dan M. Siregar, "Perancangan Website Sebagai Media Promosi Dan Penjualan Produk," Jurnal TAM (Technology Acceptance Model) Vol.19 No.1 Juli, p. 15, 2018.

[5] E. Y. Anggraeni dan R. Irviani, Pengantar Sistem Informasi, Yogyakarta: Andi, 2017, p. 2.

[6] S. Lindawati, M. Hendri dan J. Hutahaean, Pemasaran Digital, Medan: Yayasan Kita Menulis, 2020, p. 4.

[7] A. Kusumawardana dan N. Hidayati, Jago Buat Website, Malang: CV. Multimedia Edukasi, 2020, p. 1.

[8] J. Enterprise, HTML, PHP Dan MySQL Untuk 
Pemula, Jakarta: PT Elex Media Komputindo, 2018, p. 1.

[9] Supono dan V. Putratama, Pemrograman Web Dengan Menggunakan PHP Dan Framework Codeigniter, Yogyakarta: Deepublish, 2018, p. 5.

[10] E. Tiara, X. Sika dan J. Devitra, "Perancangan Sistem Informasi E-commerce Pada Butik Rumah Warna Jambi," Junrnal Ilmiah Mahasiswa Sistem Informasi Vol. 1 No. 4 Desember, p. 334, 2019.

[11] Marini dan Sarwindah, "Implementasi Web Elektronik (E-Commerce) Di Toko Pecah Belah Center Dalam Meningkatkan Persaingan Bisnis Perdagangan," Jurnal Teknologi Informasi Vol.4 No.1 Juni, p. 85, 2020.

[12] H. A. Fatta, Analisis dan Perancangan Sistem Informasi untuk Keunggulan Bersaing Perusahaan dan Organisasi Modern, Yogyakarta: C.V Andi, 2007.

[13] A. Firdianti, Implementasi Manajemen Berbasis Sekolah Dalam Meningkatkan Prestasi Belajar Siswa, Yogyakarta: CV. Gre Publishing, 2018, p. 19. 